\title{
The development of specific rRNA-derived oligonucleotide probes for Haemophilus ducreyi, the causative agent of chancroid
}

\author{
Rudi Rossau, ${ }^{*}$ Maddy Duhamel, Geert Jannes, Jean Luc Decourt and \\ Hugo VAN HeUVERSWYN
}

Innogenetics NV, Industriepark 7, Box 4, B-9052 Zwijnaarde, Belgium

(Received 9 July 1990; revised 28 September 1990; accepted 9 October 1990)

\begin{abstract}
Part of a ribosomal ribonucleic acid (rRNA) cistron of Haemophilus ducreyi was enzymically amplified using conserved primers within the rRNA molecules, cloned in a plasmid vector, and sequenced. From the nucleotide sequence, eight oligonucleotides complementary to different regions in the $16 \mathrm{~S}$ and $23 \mathrm{~S}$ rRNA molecules were selected, chemically synthesized, and used as hybridization probes. Hybridization experiments with at least 41 $H$. ducreyi strains and 13 or 14 non- $H$. ducreyi strains revealed that all eight oligonucleotide probes were highly reliable and completely specific for $H$. ducreyi strains. Comparisons of 16S rRNA sequences confirm that $H$. ducreyi is a member of the Pasteurellaceae though not closely related to other species in this family.
\end{abstract}

\section{Introduction}

Haemophilus ducreyi, the causative agent of chancroid, is a fastidious Gram-negative bacterium, assigned to the genus Haemophilus by Kilian (1976) on phenotypic grounds. Casin et al. (1985) and Albritton (1989) showed that $H$. ducreyi is a homogeneous species which lacks DNA relatedness to other Haemophilus species or to other members of the family Pasteurellaceae. Based on these and other observations, Albritton (1989) questioned the inclusion of $H$. ducreyi in the family Pasteurellaceae. A recent study on the taxonomy of the Pasteurellaceae using DNA :rRNA hybridization shows that $H$. ducreyi is a distinct taxon in the family Pasteurellaceae (De Ley et al., 1990).

Although isolation and culture of $H$. ducreyi is difficult and the sensitivity of diagnosis by culture may be relatively poor, culture remains the method of choice for the diagnosis of chancroid (Ronald \& Albritton, 1984). A recent approach to the diagnosis of infectious agents makes use of DNA-probe technology (Viscidi \& Yolken, 1987; Tenover, 1988), which is particularly advantageous in the diagnosis of fastidious organisms. More recently the use of chromosomal DNA probes for the detection of growth-amplified $H$. ducreyi strains has been

Abbreviation: PCR, polymerase chain reaction.

The nucleotide sequence data reported in this paper have been submitted to GenBank and have been assigned the accession number M38751-23SV. reported (Parsons et al., 1989). However, a DNA-probe assay for this micro-organism would be especially useful if direct detection in a clinical sample could be achieved. Due to the high sensitivity required, DNA probes targeting the abundant and single-stranded rRNA molecules are preferred to probes directed against genes located on the chromosome which, in general, are present in only one or a few copies. Earlier published results showed that despite the highly conserved character of the rRNA genes, high specificities could be attained when using short oligonucleotides complementary to certain regions in the rRNA molecules as hybridization probes (Haun \& Göbel, 1987; Rossau et al., 1989). Since $H$. ducreyi seems to be genotypically homogeneous and relatively distantly related to other known bacteria (Casin et al., 1985; De Ley et al., 1990), the development of a species-specific rRNA-derived DNA probe should be feasible. Therefore, a rapid cloning system for rRNA genes was developed making use of the polymerase chain reaction (PCR) and oligonucleotide primers allocated within the more conserved regions of the rRNA molecules. The $16 \mathrm{~S}$ rRNA gene and a part of the 23S rRNA gene of $H$. ducreyi CIP $542^{\mathrm{T}}$ were cloned and sequenced. Five $16 \mathrm{~S}$ rRNA-derived oligonucleotides and three 23S rRNAderived oligonucleotides were chemically synthesized and their specificity (i.e. the ability to differentiate $H$. ducreyi organisms from others) and reliability (i.e. the ability to identify all $H$.ducreyi isolates) were evaluated. 
Alignment and signature analysis of the rRNA sequences were used to elucidate the taxonomic position of $H$. ducreyi.

\section{Methods}

Strains and culturing methods. H. ducreyi strains originating from different locations in Africa (52 strains), Asia (9 strains), Europe (14 strains) and North America (12 strains), predominantly isolated from genital ulcers, were used. These, and the reference strains of other bacterial species used, are listed in Table $1 . H$. ducreyi cells, grown on Mueller-Hinton (BBL) agar supplemented with $5 \%(\mathrm{v} / \mathrm{v})$ heated $\left(80^{\circ} \mathrm{C}\right)$ horse blood, $1 \%(\mathrm{v} / \mathrm{v})$ Isovitalex $(\mathrm{BBL})$, and $5 \%(\mathrm{v} / \mathrm{v})$ foetal calf serum (Gibco) or on GC medium (Difco) agar supplemented with $1 \%$ $(\mathrm{w} / \mathrm{v})$ bovine haemoglobin (Difco), $1 \%(\mathrm{w} / \mathrm{v})$ Isovitalex, and $5 \%(\mathrm{v} / \mathrm{v})$ foetal calf serum (Gibco) at $33-35^{\circ} \mathrm{C}$ in a $\mathrm{CO}_{2},(5 \%, v / v)$ enriched atmosphere for $48 \mathrm{~h}$, were supplied by P. Piot and collaborators (Institute of Tropical Medicine, Antwerp, Belgium).

DNA isolation. Whole-cell DNA was prepared essentially by the method of Marmur (1961). Recombinant plasmids were isolated using the method described by Kahn et al. (1979). For sequence analysis, plasmid DNA was purified using the Gene-Clean kit (BIO 101) as recommended by the manufacturers.

Preparation of the membranes. A few colonies of each isolate were scraped from the agar plate and applied to a Biodyne A transfer membrane (Pall Ultrafine Filtration Corp.). The cells were lysed by incubating the membranes at room temperature on Whatman $3 \mathrm{MM}$ filter paper saturated with $10 \%(\mathrm{w} / \mathrm{v})$ SDS. When lysis was apparent, usually after about $5 \mathrm{~min}$, the membranes were dried and baked for $2 \mathrm{~h}$ at $80^{\circ} \mathrm{C}$. Purified whole-cell DNA was fixed to nitrocellulose membranes (BA 85, Schleicher \& Schüll) as described previously (Rossau et al., 1989).

Oligonucleotide synthesis, purification and labelling. The oligonucleotides to be used as primers or probes were synthesized by the phosphitetriester method on a Cyclone 8400 DNA synthesizer (New Brunswick Scientific). The protected oligonucleotides were purified on Nensorb Prep columns (DuPont, NEN Research Products) as recommended by the manufacturers. The oligonucleotides were 5 -labelled with [ $\left.\gamma^{-32} \mathrm{P}\right] \mathrm{ATP}$ and T4 polynucleotide kinase (Pharmacia) (Maniatis et al., 1982) or tailed at their $3^{\prime}$ end with digoxigenin-11-dUTP (Boehringer Mannheim) and terminal transferase (Boehringer Mannheim) in 0.1 Msodium cacodylate, $\mathrm{pH} 7.0,1 \mathrm{~mm}-\mathrm{CoCl}_{2}, 0.1 \mathrm{~mm}$-dithiothreitol and $50 \mu \mathrm{g}$ bovine serum albumin $\mathrm{ml}^{-1}$ for $30 \mathrm{~min}$ at $37^{\circ} \mathrm{C}$.

Enzymic amplification. A $2400 \mathrm{bp}$ fragment of a rRNA cistron of $H$. ducreyi $\mathrm{CIP} 542^{\mathrm{T}}$ was enzymically amplified using the PCR technique, starting from $1 \mu \mathrm{g}$ purified whole-cell DNA. The reagents supplied in the GeneAmp kit (Perkin-Elmer Cetus) were used according to the manufacturers' recommendations.

One hundred pmol of the following primers were added to a total reaction volume of $100 \mu \mathrm{l}$ : TGGCTCAGAT TGAACGCTGG CGGC (primer 1) and CCTTTCCCTC ACGGTACTGG T (primer 2). After initial denaturation at $95^{\circ} \mathrm{C}$ for $4 \mathrm{~min}, 30$ cycles were performed. Annealing was carried out for $2.5 \mathrm{~min}$ at $37^{\circ} \mathrm{C}$, extension for $3.5 \mathrm{~min}$ at $72{ }^{\circ} \mathrm{C}$, and denaturation for $1.5 \mathrm{~min}$ at $95^{\circ} \mathrm{C}$. After $10 \mathrm{~min}$ incubation at $72^{\circ} \mathrm{C}$ and cooling to room temperature, the mixture was extracted with $200 \mu \mathrm{CHCl}_{3}$. The aqueous phase was then recovered and the nucleic acids precipitated overnight at $-20^{\circ} \mathrm{C}$ with $0.3 \mathrm{M}$-sodium acetate and 2 vols ethanol. The pellet was dissolved in $20 \mu 10 \mathrm{~mm}$-Tris/ $\mathrm{HCl}$ (pH 7.6), $1 \mathrm{~mm}$-EDTA (TE), loaded onto a $1 \%$ $(\mathrm{w} / \mathrm{v})$ agarose gel, and electrophoresed for about $90 \mathrm{~min}$ at $8 \mathrm{~V} \mathrm{~cm}-1$.
Table 1. Strains used

\begin{tabular}{|c|c|c|}
\hline Taxon & Origin & $\begin{array}{l}\text { No. of strains and/or } \\
\text { collection no.* }\end{array}$ \\
\hline Haemophilus ducreyi & $\begin{array}{l}\text { South Africa } \\
\text { Kenya } \\
\text { Rwanda } \\
\text { Zaire } \\
\text { Thailand } \\
\text { Sri Lanka } \\
\text { Vietnam } \\
\text { USA } \\
\text { Canada } \\
\text { Mexico } \\
\text { The Netherlands } \\
\text { Denmark } \\
\text { France } \\
\text { Belgium } \\
\text { Unknown }\end{array}$ & $\begin{array}{r}17 \\
6 \\
23 \\
6 \\
7 \\
1 \\
1 \\
3 \\
8 \\
1 \\
7 \\
2 \\
3 \\
2 \\
2\end{array}$ \\
\hline $\begin{array}{l}\text { Escherichia coli } \\
\text { Actinobacillus actino- }\end{array}$ & & $2(\mathrm{MC} 1061$ and $\mathrm{B})$ \\
\hline $\begin{array}{l}\text { mycetemcomitans } \\
\text { Actinobacillus lignieresii }\end{array}$ & & $\begin{array}{l}\text { NCTC } 9710^{\mathrm{T}} \\
\text { NCTC } 4189^{\mathrm{T}}\end{array}$ \\
\hline Haemophilus aphrophilus & & $\begin{array}{l}\text { NCTC } 4189^{1} \\
\text { NCTC } 5906^{T}\end{array}$ \\
\hline Haemophilus influenzae & & NCTC $8143^{\mathrm{T}}$ \\
\hline $\begin{array}{l}\text { Histophilus ovis } \\
\text { Pasteurella multocida }\end{array}$ & & $\begin{array}{l}\text { HIM } 896-7 \\
\text { NCTC } 10322^{\mathrm{T}}\end{array}$ \\
\hline Moraxella catarrhalis & & ITM 4197 \\
\hline Comamonas testosteroni & & ATCC 17407 \\
\hline Oligella urethralis & & LMG 6227 \\
\hline Neisseria gonorrhoeae & & ITM 4437 \\
\hline Campylobacter jejuni & & CCUG $11284^{\mathrm{T}}$ \\
\hline Acinetobacter calcoaceticus & & ATCC $23055^{\mathrm{T}}$ \\
\hline
\end{tabular}

* ATCC, American Type Culture Collection, Rockville, MD, USA; CCUG, Culture Collection of the University of Göteborg, Department of Clinical Bacteriology, University of Göteborg, Sweden; CIP, Collection de l'Institut Pasteur, Paris, France; HIM, Hygiene-Institut, Marburg, FRG; ITM, Institute for Tropical Medicine, Antwerp, Belgium; LMG, Laboratorium voor Microbiologie, Rijksuniversiteit, Gent, Belgium; NCTC, National Collection of Type Cultures, Central Public Health Laboratory, London, UK; ${ }^{\mathrm{T}}$, type strain.

The gel portion containing the amplified DNA fragment of about 2400 bp was removed and the DNA eluted by centrifugation through an HVLP 025000 membrane filter (Millipore). The eluate was then extracted using phenol and ether, and the DNA precipitated with ethanol. The DNA was redissolved in $20 \mu \mathrm{T} \mathrm{TE}$ and used for restriction analysis and cloning.

Cloning. The gel-purified 2400 bp PCR fragment was treated with Klenow enzyme to create blunt ends as described by Maniatis $e t$ al. (1982), and the fragment was then further digested with $X b a I$. After overnight ligation at $15^{\circ} \mathrm{C}$ with SmaI-XbaI-digested pSPT19 (Pharmacia), transformation in competent Escherichia coli MC1061 and overnight culture on Luria-Bertani agar containing ampicillin $(0.1 \mathrm{mg}$ $\mathrm{ml}^{-1}$ ), clone analysis was performed on 16 colonies, as described by Birnboim \& Doly (1979).

Nucleic acid sequence determination. The inserts of the recombinants were sequenced using the dideoxy chain-termination method (Sanger $e t$ al., 1977) modified according to the protocol for double-stranded templates given in the reagent kit for DNA sequencing with Sequenase (United States Biochemical). Oligonucleotides complementary to sequences adjacent to the plasmid inserts or allocated in conserved 
areas of the rRNA genes were used as primers. Sequence comparison was done using the PC/GENE software provided by Intelligenetics Inc. and Genofit SA.

Hybridizations. Biodyne A membranes on which bacterial colonies were fixed were prehybridized in a mixture containing the following components: $3 \times \mathrm{SSC}(1 \times \mathrm{SSC}$ is $0.15 \mathrm{M}-\mathrm{NaCl}$ plus $0.015 \mathrm{M}$-sodium

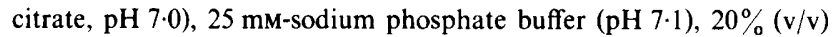
deionized formamide, $0.02 \%$ Ficoll (type 400 ; Sigma), $0.02 \%$ bovine serum albumin, $0.02 \%$ polyvinylpyrrolidone, $0.1 \mathrm{mg}$ sheared heatdenatured salmon sperm DNA ml ${ }^{-1}$, and $0 \cdot 2 \%$ SDS, usually for $0.5-1 \mathrm{~h}$ at the appropriate temperature. The hybridization mixture had the same composition except that approximately $10^{6} \mathrm{c}$.p.m. of ${ }^{32} \mathrm{P}$-labelled probe $\mathrm{ml}^{-1}$ was added. Hybridizations were performed at the same temperature for 1-2 h. The membranes were washed for $30 \mathrm{~min}$ in $3 \times$ SSC, 25 mm-sodium phosphate buffer $(\mathrm{pH} 7 \cdot 1), 20 \% \quad(\mathrm{v} / \mathrm{v})$ deionized formamide, $0.2 \%$ SDS at the hybridization temperature. Nitrocellulose membranes (BA 85) were processed similarly except that SDS was omitted from the mixtures. Fuji RX film (Fuji Photo Film) was used for autoradiography. Hybridizations with digoxigeninlabelled probes were performed as described in the protocol sheet of the DNA labelling and detection kit nonradioactive (Boehringer) except that $3 \times$ SSC instead of $5 \times$ SSC was used and that the mixture contained $20 \%(\mathrm{v} / \mathrm{v})$ deionized formamide unless otherwise stated. About 1 pmol digoxigenin-labelled probe was used per $\mathrm{ml}$ hybridization mixture.

\section{Results}

\section{Enzymic amplification and cloning}

For the enzymic amplification, conserved primers allocated about $40 \mathrm{bp}$ from the $5^{\prime}$ end of the 16S rRNA gene and about $450 \mathrm{bp}$ from the $5^{\prime}$ end of the $23 \mathrm{~S}$ rRNA gene were used (Fig. 1). As expected, enzymic amplification with these primers yielded a dominant product about $2400 \mathrm{bp}$ in length and some minor fragments. The $2400 \mathrm{bp}$ fragment was clearly visible on an ethidiumbromide-stained $1 \%$ agarose gel after electrophoresis of $10 \%$ of the total amplification reaction yield starting from $1 \mu \mathrm{g}$ purified whole-cell DNA from $H$. ducreyi CIP $542^{\mathrm{T}}$ (results not shown). Restriction endonuclease analysis of the purified $2400 \mathrm{bp}$ PCR fragment revealed a unique restriction site for $X b a \mathrm{I}$. Digestion of the amplified fragment with $X b a I$ enabled the directional cloning of two XbaI blunt fragments of about $1600 \mathrm{bp}$ and $800 \mathrm{bp}$, respectively, in the vector pSPT19 digested with SmaI and $X b a I$. Of the 16 clones analysed, one carried the $1600 \mathrm{bp}$ fragment and six the $800 \mathrm{bp}$ fragment. The resulting recombinant plasmids containing the $1600 \mathrm{bp}$ and $800 \mathrm{bp}$ fragments, respectively, were named pHDA1 and pHDA2 (Fig. 1). To facilitate the sequencing of the $16 \mathrm{~S}$ and $23 \mathrm{~S}$ rRNA genes, the subclones pHDA3, pHDA4, and pHDA6 were constructed by making use of the available restriction sites (see Fig. 1).

\section{Nucleic acid sequence analysis}

The sequencing reactions performed are indicated in Fig. 1. Dideoxy chain-termination sequencing on the purified plasmid DNA resulted in clearly readable sequencing ladders with only a few ambiguities. The nucleotide sequences of the 16S rRNA gene (except for about 40 nucleotides at the $5^{\prime}$ end) and the first 456 nucleotides at the $5^{\prime}$ end of the 23S rRNA gene are shown in Fig. 2(a) and Fig. 2(b), respectively. In the $16 \mathrm{~S}$ and 23S rRNA genes all overlaps were obtained. The $3^{\prime}$ end of the $16 \mathrm{~S}$ rRNA gene and the $5^{\prime}$ end of the 23S rRNA gene were determined by analogy with the $E$. coli sequences (Brosius et al., 1981). The $\mathrm{G}+\mathrm{C}$ content of the $16 \mathrm{~S}$ rRNA gene was $51.7 \mathrm{~mol} \%$, while that of the $5^{\prime}$ end of the $23 \mathrm{~S}$ rRNA gene was $43.9 \mathrm{~mol} \%$. The base composition of the genome of $H$. ducreyi CIP $542^{\mathrm{T}}$ is approximately $39 \mathrm{~mol} \% \mathrm{G}+\mathrm{C}$ (Casin et al., 1985; De Ley et al., 1990).

The sequences were aligned with published sequences using the Fast scan program of PC/GENE and the percentage homology was calculated. The homology values obtained with partial $16 \mathrm{~S}$ rRNA sequences of members of the Pasteurellaceae [regions A and B as described by Chuba et al. (1988)] and with $16 \mathrm{~S}$ and $23 \mathrm{~S}$ rRNA sequences of some other representative bacterial taxa are shown in Table 2. The homology values for region $\mathrm{B}$ and particularly for region $\mathrm{A}$ were lower than those obtained with virtually complete $16 \mathrm{~S}$ rRNA sequences. However, when regions $A$ and $B$ were combined, all homology values with members of the Pasteurellaceae (86-93\%) were higher than those obtained with other bacterial taxa $(75-85 \%)$. From Table 2, it can also be inferred that the sequenced $5^{\prime}$ part of the 23S rRNA was not highly conserved.

Ninety-two of the 95 16S rRNA signature nucleotides of the purple bacteria (now named Proteobacteria; Stackebrandt et al., 1988) as defined by Woese (1987) could be deduced. The sequence signature of $H$. ducreyi CIP $542^{\mathrm{T}}$ was highly similar to the sequence signature of gamma subdivision organisms. Only the following four of the 92 signature nucleotides compared differed from those of the gamma subdivision: (i) $\mathrm{U}$ instead of $\mathrm{G}$ at positions 718 and 760 in $H$. ducreyi (numbering as in Fig. 2) and $E$. coli (numbering as in Woese, 1987), respectively; (ii) A instead of $G$ or $U$ at positions 1216 and 1260 , respectively; (iii) $U$ instead of $G$ at positions 1253 and 1297, respectively; and (iv) $A$ instead of $G$ at positions 1254 and 1298, respectively. Twenty-two signature positions between $H$. ducreyi and members of the Pasteurellaceae (Chuba et al., 1988) could be compared and were found to be completely identical except that at position 390 ( $E$. coli numbering), C instead of $\mathrm{U}$ was found in some species. It is striking, and most probably 

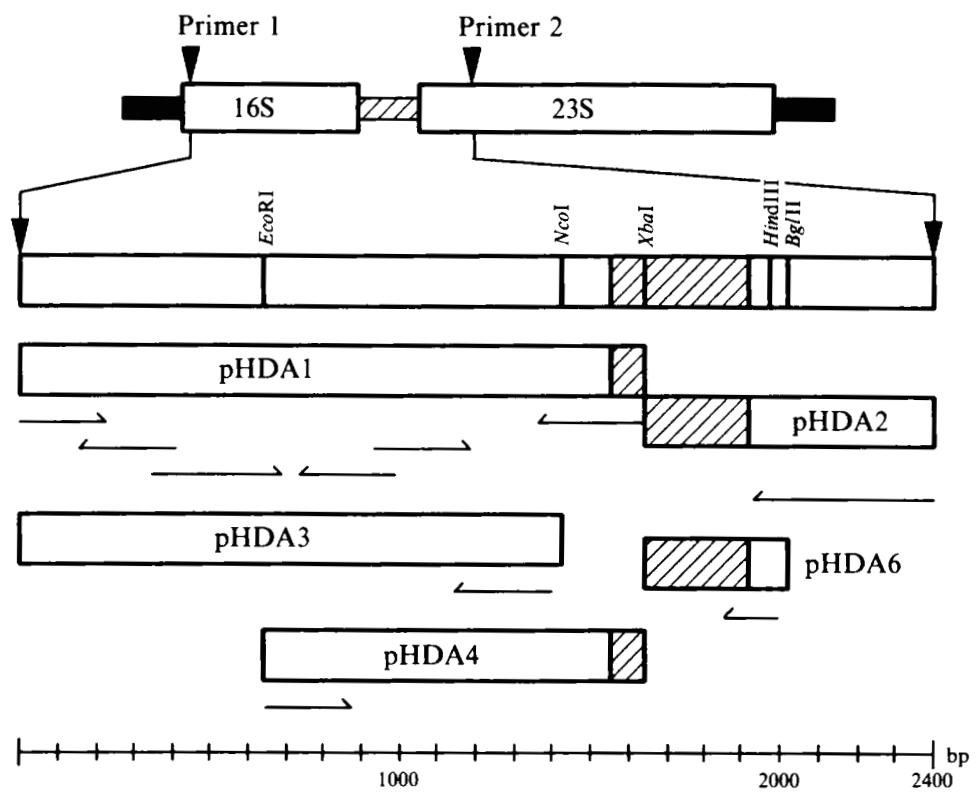

Fig. 1. Enzymic amplification, cloning, subcloning, and sequencing scheme for a 2400 bp rRNA gene fragment of $H$. ducreyi CIP $542^{\mathrm{T}}$. The PCR fragment is indicated between black vertical arrowheads. The hatched area is the spacer region between the $16 \mathrm{~S}$ and the 23S rRNA gene. The sequencing reactions are indicated by horizontal arrows. The locations of some relevant restriction sites are also indicated. (a)

10

20

1 GCAGGCTTAA CACATGCAAG TCGAACGGTA 61 TGGCGGACGG GTGAGTAATG CTTGGGAATC TGGCTTATGG AGGGGGATAA CTACGGGAAA 121 CTGTAGCTAA TACCGCGTAA TATCTTCGGA TTAAAGGGTG GGACCTTCGG GCCACCTGCC 181 ATAAGATGAG CCCAAGTGG ATTAGGTAGT TGGTTAGGTA AAGGCTGACC AAGCCGACGA 241 TCTCTAGCTG GTCTGAGAGG ATGACCAGCC ACACTGGAAC TGAGACACGG TCCAGACTCC 301 TACGGGAGGC AGCAGTGGGG AATATTGCAC AATGGGGGAA ACCCTGATGC AGCCATGCCG 361 CGTGAATGAA GAAGGCCTTC GGGTTGTAAA GTTCTTTCGG TGATGAGGAA GGCAGTTTTG 421 TTAATAGCAA AATTGATTGA CGTTAGTCAC AGAAGAAGCA CCGGCTAACT CCGTGCCAGC 481 AGCCGCGGTA ATACGGGGGG TGCGAGCGTT AATCGGAATA ACTGGGCGTA AAGGGCACGC 541 AGGCGGTTGA TTAAGTGAGA TGTGAAAGCC CCGGGCTTAA CCTGGGAATT GCATTTCATA 601 CTGGTCAACT AGAGTACTTT AGGGAGGGGT AGAATTCCAC GTGTAGCGGT GAAATGCGTA 661 GAGATGTGGA GGAATACCGA AGGCGAAGGC AGCCCCTTGG GAATGTATNG ANNCTCATGT 721 GCGAAAGCGT GGGGAGCAAA CAGGATTAGA TACCCTGGTA GTCCACGCTG TAAACGATGT 781 CGATTTGGGG GTTGGTCTTT AAGACTGGCG CCCGAAGCTA ACGTGATAAA TCGACCGCCT 841 GGGGAGTACG GCCGCAAGGT TAAAACTCAA ATGAATTGAC GGGGGCCCGC ACAAGCGGTG 901 GAGCATGTGG TTTAATTCGA TGCAACGCGA AGAACCTTAC CTACTCTTGA CATCCATAGA 961 AGAACTCAGA GATGAGTTTG TGCCTTCGGG AACTATGTGA CAGGTGCTGC ATGGCTGTCG 1021 TCAGCTCGTG TTGTGAAATG TTGGGTTAAG TCCCGCAACG AGCGCAACCC TTATCCTTTG 1081 TTGCCAGCAT GTAATGATGG AACTCAAAGG AGACTGCCAG TGATAAACTG GAGGAAGGTG 1141 GGGATGACGT CAAGTCATCA TGGCCCTTAC GAGTAGGGCT ACACACGTGC TACAATGGCG 1201 TATACAGAGG GCGGCAAACC TGCAAAGGG AGCGAATCTC ACAAAGTACG TCTAAGTCCG 1261 GATTGGAGTC TGCAACTCGA CTCCATGAAG TCGGAATCGC TAGTAATCGC AAATCAGAAT 1321 GTTGCGGTGA ATACGTTCCC GGGCCTTGTA CACACCGCCC GTCACACCAT GGGAGTGGGT 1381 TGTACCAGAA GTAGATAGCT TAACCTTCGG GAGGGCGTTT ACCACGGTAT GATTCATGAC 1441 TGGGGTGAAG TCGTAACAAG GTAACCGTAG GGGAACCTGC GGTTGGATCA CCTCCTTA

(b)

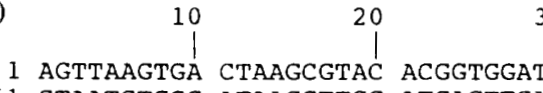

1 AGTTAAGTGA CTAAGCGTAC ACGgTGGATG CCTTGGCAAT CAGAGGCGAT GAAGGACGTG 61 CTAATCTGCG ATAAGCTTGG ATGAGTTGAT CAAGAAACGT ATAATCCAAG ATCTCCGAAT 121 GGGGAAACCC ACTAGATGAT GAATCTAGTA TTTATTACCC AATACATAAG TAATAAAAGC 181 AAACCGGGAG AACTGAAACA TCTAAGTAAC CCGAGGAAAA GAAATCAACC GAGATTCCGT 241 TAGTAGCGGC GAGCGAACGT GGAAAAGCCA GTTAGTGATA ACCCATACAT TAGAGGAAGT 301 AGCTGGGAAG CTACATCATA GAGGGAGATA ATCCCGTACT CGAAAATATG TGGGCCGTAC 361 TAAACTAACA ACAAGTAAGG CGGGACACGA GAAATCCTGT CTGAAGATGG GNNNACCATC 421 CTCCAAGGCT AAATACTCCT GATTGACCGA TAGTGA
Fig. 2. Nucleotide sequences of the non-coding strand of the $16 \mathrm{~S}$ rRNA gene $(a)$ and the $5^{\prime}$ end of the $23 \mathrm{~S}$ rRNA gene (b) of $H$. ducreyi CIP $542^{\top}$. Approximately $40 \mathrm{bp}$ at the $5^{\prime}$ end of the 16S rRNA gene could not be determined. $\mathrm{N}$ refers to nucleotides which could not be determined unambiguously. 
Table 2. Percentage sequence homology of the $r R N A$ sequences of Haemophilus ducreyi CIP $542^{\mathrm{T}}$ with those of other bacterial taxa

In columns $\mathrm{A}$ and $\mathrm{B}$ the percentage homology of the regions in the 16S rRNA molecule for which sequences of members of the Pasteurellaceae are published (A and B, respectively, in Chuba et al., 1988) is given. The total homology of region A plus B is shown in column $\mathrm{A}+\mathrm{B}$. The percentage homology with the virtually complete $16 \mathrm{~S}$ rRNA sequence and the $5^{\prime}$ part of the $23 \mathrm{~S}$ rRNA sequence is given in columns $16 \mathrm{~S}$ and $23 \mathrm{~S}$, respectively. The percentage homology was calculated by dividing the total number of matches by the total number of nucleotides compared. The total number of nucleotides used in the calculation is indicated between parentheses.

Source of the sequences: $a$, Chuba et al. (1988); $b$, Brosius et al. (1981); c, Carbon et al. (1981); $d$, unpublished results (R. Rossau and others); $e$, Toschka et al. $(1987,1988) ; f$, Rossau et al. (1988 and unpublished results); $g$, Dorsch et al. (1989).

\begin{tabular}{lccccc}
\hline \hline & \multicolumn{5}{c}{ Percentage sequence homology } \\
\cline { 2 - 6 } & $\mathrm{A}$ & $\mathrm{B}$ & $\mathrm{A}+\mathrm{B}$ & $16 \mathrm{~S}$ & $23 \mathrm{~S}$ \\
& $(100)$ & $(345)$ & $(445)$ & $(1489)$ & $(456)$ \\
\hline Actinobacillus hominis $^{a}$ & 83 & 96 & 93 & - & - \\
Actinobacillus equuli $^{a}$ & 79 & 95 & 91 & - & - \\
Actinobacillus lignieresii $^{a}$ & 80 & 93 & 90 & - & - \\
Haemophilus influenzae $^{a}$ & 82 & 93 & 90 & - & - \\
Actinobacillus actino- $^{\text {mycetemcomitans }}{ }^{a}$ & 88 & 90 & 89 & - & - \\
Haemophilus aphrophilus $^{a}$ & 82 & 89 & 87 & - & - \\
Pasteurella multocida $^{a}$ & 84 & 87 & 86 & - & - \\
Escherichia coli $^{b}$ & 81 & 86 & 85 & 89 & 77 \\
Proteus vulgaris $^{c}$ & 78 & 86 & 84 & 87 & - \\
Moraxella catarrhalis $^{d}$ & 78 & 83 & 82 & 84 & 67 \\
Pseudomonas aeruginosa $^{e}$ & 76 & 79 & 78 & 83 & 75 \\
Neisseria gonorrhoeae $^{f}$ & 78 & 80 & 79 & 81 & 76 \\
Brucella abortus $^{\natural}$ & 72 & 75 & 75 & 78 & - \\
\hline \hline
\end{tabular}

not without significance, that $\mathrm{U}$ instead of $\mathrm{G}$ is also found in position 760 (E. coli numbering) in the $16 \mathrm{~S}$ rRNA sequences of all members of the Pasteurellaceae published so far (Chuba et al., 1988). The nucleotides in positions 1260,1297 , and 1298 (E. coli numbering) were not comparable.

The secondary structures of the $16 \mathrm{~S}$ rRNA and the $5^{\prime}$ end of the $23 \mathrm{~S}$ rRNA were essentially identical to the consensus structures respectively proposed by Dams et al. (1988) and by both Gutell \& Fox (1988) and Höpfl $e t$ al. (1989). The higher-order structure of the region between positions 180 and 220 (E. coli numbering) of the $16 \mathrm{~S}$ rRNA of $H$. ducreyi is identical to that of beta and gamma subdivision organisms (Woese, 1987).

\section{Probe specificity and reliability}

From the available sequence information, subsequences allocated in variable regions of the $16 \mathrm{~S}$ and $23 \mathrm{~S}$ rRNA molecules (as described in Rossau et al., 1989) were
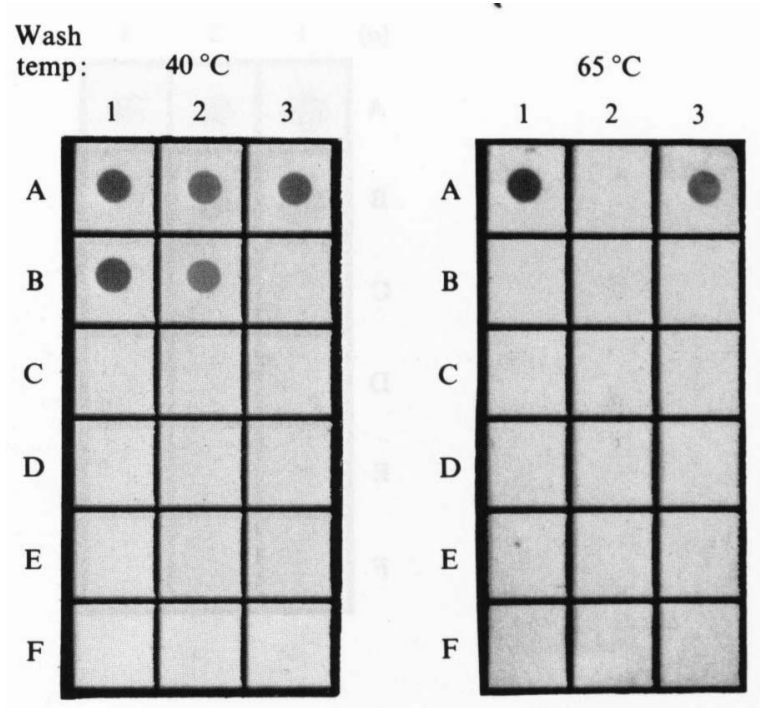

Fig. 3. Specificity and reliability of digoxigenin-labelled probe 8 at different wash conditions. One microgram of dot-spotted denatured genomic DNA was hybridized and washed at 40 or $65^{\circ} \mathrm{C}$. At $65^{\circ} \mathrm{C}$ the hybridization and wash mixtures did not include formamide; this corresponds to about $50{ }^{\circ} \mathrm{C}$ in mixtures with $20 \%(\mathrm{v} / \mathrm{v})$ formamide. Row A, and B1 and B2, Haemophilus ducreyi strains; B3, Escherichia coli; C1, Actinobacillus actinomycetemcomitans; C2, Actinobacillus lignieresii; C3, Haemophilus aphrophilus; D1, Haemophilus influenzae; D2, Histophilus ovis, D3, Pasteurella multocida; E1, Moraxella catarrhalis; E2, Comamonas testosteroni; E3, Oligella urethralis; F1, Neisseria gonorrhoeae; F2, Campylobacter jejuni; F3, Acinetobacter calcoaceticus.

selected. The target regions of probes 2 and 3 were compared with published sequences of other members of the Pasteurellaceae; at least four mismatches were found. In the target regions of all the probes tested at least six mismatches were observed with organisms not belonging to the Pasteurellaceae. Oligonucleotides varying from 20 to 28 nucleotides in length and complementary to these selected sequences were chemically synthesized, labelled and used as hybridization probes.

The probes were hybridized at different temperatures with dot-spotted whole-cell DNA of five $H$. ducreyi strains and several strains of other bacterial taxa including six strains belonging to different species in the family Pasteurellaceae. At stringent hybridization and wash temperatures (i.e. about $5{ }^{\circ} \mathrm{C}$ below the experimental dissociation temperature, $T_{\mathrm{d}}$, of the probe-target hybrid), none of the probes cross-hybridized with non- $H$. ducreyi strains. This is illustrated in Figs 3 and 4(a) for probes 8 and 7 , respectively. The results obtained with all probes tested are summarized in Table 3.

Between 41 and $89 \mathrm{H}$. ducreyi strains isolated in different continents were screened at the hybridization and wash temperatures at which the probes were specific for $H$. ducreyi (Table 3). Either dot-spotted purified whole-cell DNA or colonies directly applied to nylon 

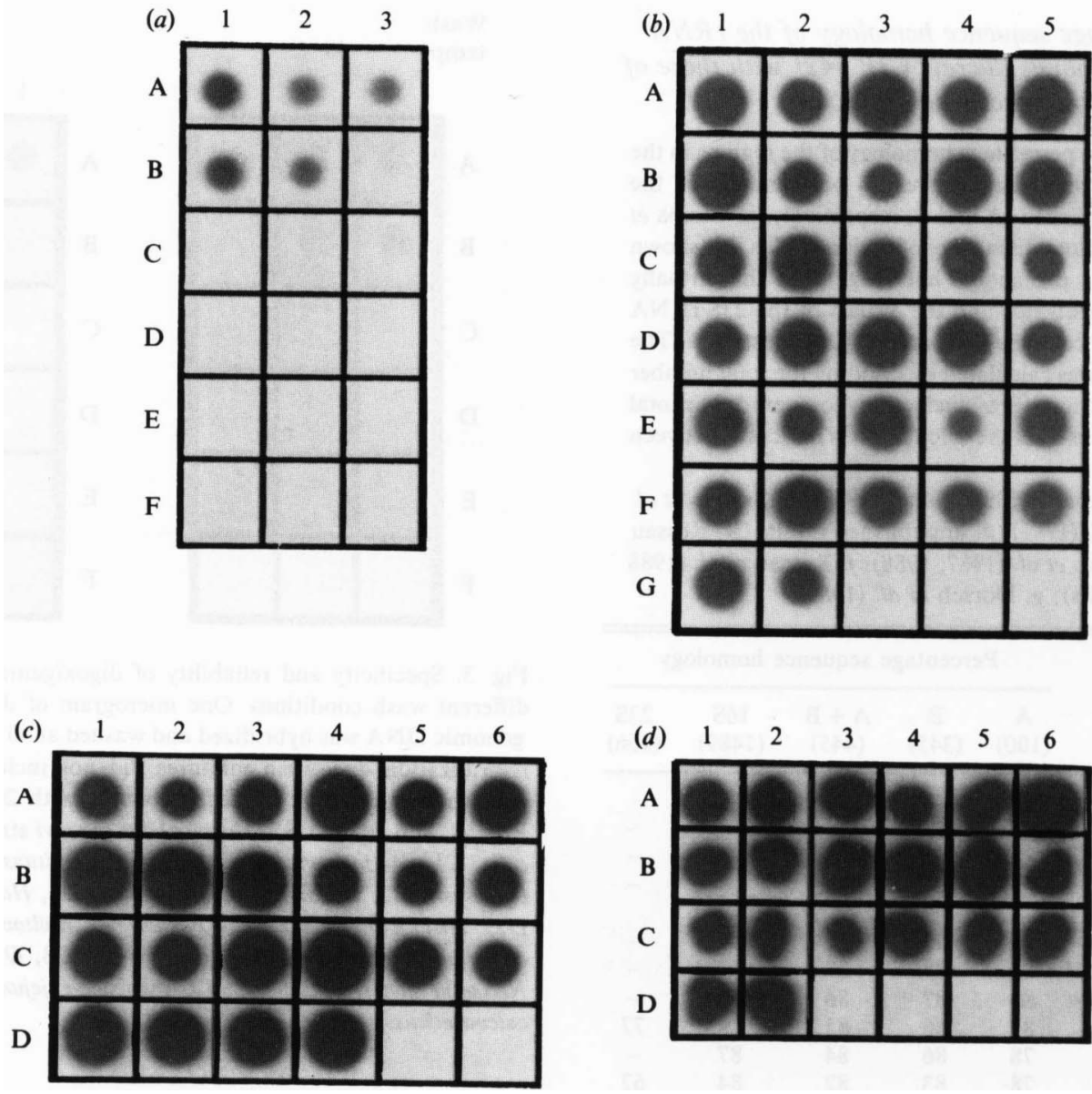

(d) $\quad 1 \quad 2 \quad 2 \quad 3 \quad 14 \quad 5 \quad 6$

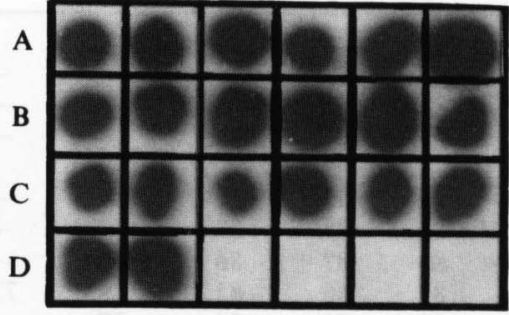

Fig. 4. Specificity and reliability of ${ }^{32} \mathrm{P}$-labelled probe 7 . In $(a)$ to $(c), 1 \mu \mathrm{g}$ of denatured genomic DNA was applied to a nitrocellulose membrane, and in $(d)$, bacterial colonies scraped from an agar plate were applied to a Biodyne A membrane and hybridized and washed at $40^{\circ} \mathrm{C}$. (a) For the location of the organisms see legend to Fig. 3. (b) Rows A-F, and G1 and G2, H. ducreyi strains; G3, Haemophilus influenzae; G4, Escherichia coli; no DNA was spotted on G5. (c) Rows A-C, and D1-D4, $H$. ducreyi strains; D5, Haemophilus influenzae; D6, Actinobacillus actinomycetemcomitans. (d) Rows A-C, and D1 and D2, Haemophilus ducreyi strains; D3, Escherichia coli; no material was applied on D4, D5 and D6.

Table 3. Summary of specificity and reliability tests with $H$. ducreyi-specific DNA probes

\begin{tabular}{|c|c|c|c|c|c|}
\hline \multirow[b]{2}{*}{ Probe } & \multirow[b]{2}{*}{ rRNA } & \multirow{2}{*}{$\begin{array}{l}\text { Length } \\
\text { (bases) }\end{array}$} & \multicolumn{2}{|c|}{$\begin{array}{l}\text { No. positive strains/ } \\
\text { no. strains tested }\end{array}$} & \multirow{2}{*}{$\begin{array}{c}\text { Hybridization } \\
\text { and wash } \\
\text { temp. }\left({ }^{\circ} \mathrm{C}\right)\end{array}$} \\
\hline & & & H. ducreyi & non- $H$. ducreyi & \\
\hline 1 & $16 S$ & 25 & $70 / 70$ & $0 / 14$ & 45 \\
\hline 2 & $16 S$ & 28 & $85 / 85$ & $0 / 14$ & 50 \\
\hline 3 & $16 \mathrm{~S}$ & 28 & $89 / 89$ & $0 / 14$ & 57 \\
\hline 4 & $16 S$ & 29 & $51 / 51$ & $0 / 13$ & 50 \\
\hline 5 & $16 \mathrm{~S}$ & 24 & $41 / 41$ & $0 / 13$ & 55 \\
\hline 6 & $23 \mathrm{~S}$ & 28 & $68 / 68$ & $0 / 14$ & 45 \\
\hline 7 & $23 \mathrm{~S}$ & 20 & $70 / 70$ & $0 / 13$ & 40 \\
\hline 8 & $23 \mathrm{~S}$ & 28 & $87 / 87$ & $0 / 14$ & 40 \\
\hline
\end{tabular}


membranes was used as target as illustrated in Fig. 4 for probe 7 . The results are also summarized in Table 3 ; all probes gave unequivocal positive hybridization signals with all $H$. ducreyi strains tested at the hybridization and wash temperatures indicated. However, as shown in Fig. 3 , probe 8 no longer proved reliable when used at higher stringencies.

\section{Discussion}

Chancroid and its aetiological agent, Haemophilus ducreyi, have gained more interest in the last few years because of its increased incidence in industrialized countries and its association with human immunodeficiency virus infection (Albritton, 1989; Morse, 1989). Generally the diagnosis of chancroid is established on a clinical basis. However, this has proven to be less than adequate since ulcers may also be caused by other infectious agents such as herpes simplex virus or Treponema pallidum. Diagnosis based on microscopy of ulcer material after Gram staining or by an indirect fluorescent antibody technique (Denys et al., 1978) is not recommended. Recently developed immunoassays are not entirely satisfactory for a reliable diagnosis of $\boldsymbol{H}$. ducreyi (Museyi et al., 1988; Schalla et al., 1986). The definite diagnosis of $H$. ducreyi can be made only by culture, but the sensitivity of this method is poor. Thus, there is a definite need for a more reliable and rapid diagnostic technique for $H$. ducreyi. DNA-probe technology may fulfil this need. For reasons already mentioned, techniques using probes which target the rRNA are most promising.

In order to develop $H$. ducreyi-specific nucleic acid probes targeting rRNA, part of a rRNA cistron of the type strain (CIP $452^{\mathrm{T}}$ ) was amplified in vitro using PCR with primers complementary to conserved regions in the $16 \mathrm{~S}$ and $23 \mathrm{~S}$ rRNA genes. Using such primers and a relatively small amount $(1 \mu \mathrm{g})$ of whole-cell DNA, a $2400 \mathrm{bp}$ fragment could readily be amplified. Unpublished results from our laboratory indicated that large amounts of amplified fragments, up to about $4500 \mathrm{bp}$ in length, can be obtained from a variety of organisms starting from the amount of unpurified DNA present in one bacterial colony. Consequently this technique is particularly useful for obtaining sequence information from micro-organisms such as $H$. ducreyi for which mass cultures are difficult to produce or when the isolation of intact $16 \mathrm{~S}$ or $23 \mathrm{~S}$ rRNA molecules is problematic. Sequence comparison of a rRNA gene of the Neisseria gonorrhoeae type strain cloned conventionally (Rossau et al., 1988) or cloned via the PCR technique revealed no differences ( $R$. Rossau and others, unpublished observations), thereby confirming the fidelity of the technique as claimed by Medlin et al. (1988).
After the amplification step, the fragment was gelpurified, cloned in a plasmid vector, and sequenced as shown in Fig. 1. This approach was favoured over direct sequencing of purified rRNA (Lane et al., 1985) or enzymically amplified material without cloning (Edwards et al., 1989) for several practical reasons. Firstly, mass culture and rRNA purification is avoided since the procedure only requires a small amount of genomic DNA, which can easily be obtained. Secondly, the sequence information coming from purified plasmid templates is very reliable, in contrast to directly sequenced PCR material. The opposite strand is also available for sequencing, in contrast to direct rRNA sequencing. Thirdly, the sequence information obtained is more complete as compared with direct rRNA sequencing; only about 40 nucleotides at the $5^{\prime}$ end of the $16 \mathrm{~S}$ rRNA gene cannot be sequenced. Furthermore, if desired, 23S rRNA sequences and spacer region sequences can also be determined using the same clones. Comparable strategies for sequencing rRNA genes have been successfully employed recently by Medlin et al. (1988) and Huss \& Sogin (1989). Arguments corroborating the correctness of the rRNA gene sequences shown in Fig. 2 are: (i) conserved nucleotides matched with those of other published sequences (Dams et al., 1988); (ii) a comparable secondary structure could be obtained (see Results); (iii) mutations in stem structures were compensated by other mutations; and (iv) no differences were found in regions sequenced on opposite strands.

Comparison of rRNA molecular sequences, in particular the $16 \mathrm{~S}$ rRNA, is a very important tool for studying the evolutionary relationships of organisms. Extensive studies have always been hampered by the timeconsuming cloning of the rRNA genes. The PCRassisted cloning of rRNA genes as described in this study and recently by other investigators (Medlin et al., 1988; Huss \& Sogin, 1989) offers a fast and reliable alternative to the direct rRNA sequencing method of Lane et al. (1985).

In Bergey's Manual of Systematic Bacteriology, $H$. ducreyi is listed as an unequivocal Haemophilus species in the family Pasteurellaceae (Kilian \& Biberstein, 1984). However, its inclusion in the genus Haemophilus was solely based on morphological characteristics, X-factor requirements, and the $\mathrm{mol} \% \mathrm{G}+\mathrm{C}$ of the genome. By themselves, these features have limited taxonomic significance, and until recently, no substantial evidence was available in support of the present classification of $H$. ducreyi. By contrast, Carlone et al. (1988) showed that the isoprenoid quinone structure of $H$. ducreyi is essentially different from that of other Haemophilus species. Casin et al. (1985) and Albritton (1989) could not detect significant levels of DNA homology between $H$. ducreyi and Haemophilus, Actinobacillus, or Pasteurella 
species, nor could Albritton et al. (1986) demonstrate significant competition for homospecific transformation with Haemophilus influenzae. DNA:rRNA hybridization results recently published by De Ley et al. (1990) corroborated these findings and established that $H$. ducreyi was a member of the Pasteurellaceae but did not belong to one of the three authentic genera in this family. From the analysis of the rRNA sequences of the type strain of $\boldsymbol{H}$. ducreyi (CIP 542 $)$, it can be inferred that $\boldsymbol{H}$. ducreyi is related to the Pasteurellaceae branch of the gamma subdivision of the Proteobacteria. However, $H$. ducreyi seems not to be specifically related to any of the Actinobacillus, Haemophilus, or Pasteurella species used by Chuba et al. (1988) (see Table 2); in fact, the homology values obtained with these species suggest a relationship at or below the genus level. This is in complete agreement with the findings of De Ley et al. (1990). Nevertheless, the exact taxonomic position of $H$. ducreyi within the Pasteurellaceae on the basis of rRNA sequences must await more complete sequence data on more taxa of this complex bacterial family.

A valuable DNA probe for the laboratory diagnosis of chancroid should not hybridize to strains not belonging to the species $H$. ducreyi, and should hybridize to all $H$. ducreyi strains regardless of origin. Lack of reliability is one of the main problems encountered with serodiagnosis of $H$. ducreyi ; indeed, Asian material does not crossreact adequately with sera of African origin and vice versa (Museyi et al., 1988). The hybridization results summarized in Table 3 show that all probes tested were highly reliable and completely specific. Except for probe 8 , the hybridization experiments were performed at high stringencies (about $5^{\circ} \mathrm{C}$ below $T_{\mathrm{d}}$ ), but most of the probes did not lose their specificity at lower stringencies (about $10-15^{\circ} \mathrm{C}$ below $T_{\mathrm{d}}$ ). The fact that all the probes are completely specific suggests a rather distant relatedness of $H$. ducreyi to other taxa tested including six strains of different species in the Pasteurellaceae. The high reliability found for all probes tested indicates that $H$. ducreyi is a genotypically homogeneous taxon. This corroborates the DNA:DNA hybridization results of Casin et al. (1985). No or only minor sequence differences seem to exist in the rRNA molecules of isolates from different origins, since the probes used were derived from the most variable regions within the rRNA molecules. A higher degree of sequence variability was observed among strains of $H$. ducreyi solely in the 23S rRNA region targeted by probe 8 , but it remains to be determined whether this variability is epidemiologically relevant.

The $H$. ducreyi-specific probes described in this study can be used directly on bacterial cells immobilized and briefly lysed on nylon membranes. As such, the probes have applications for culture confirmation of $H$. ducreyi.
However, the probes may be of greater value in the rapid detection and control of chancroid if they can be combined with a non-radioactive detection system enabling noncultural diagnosis in clinical material. Since the $H$. ducreyi probes do not cross-hybridize with relatively closely related species of the genera Haemophilus, Actinobacillus, or Pasteurella, it is highly unlikely that these probes would cross-react with more remotely related organisms which may be found in urogenital samples.

We are grateful to P. Piot and collaborators (Institute of Tropical Medicine, Antwerp, Belgium) for culturing $H$. ducreyi cells and to J. De Ley and collaborators (Laboratory of Microbiology, State University of Ghent, Ghent, Belgium) for providing purified DNA of some of the reference organisms. Reinhilde Zelck and Christiane Messiaen are acknowledged for their excellent secretarial assistance and Fred Shapiro for the critical reading of the manuscript.

\section{References}

Albritton, W. L. (1989). Biology of Haemophilus ducreyi. Microbiological Reviews 53, 377-389.

Albritton, W. L., Setlow, J. K., Thomas, M. \& Sottnek, F. O. (1986). Relatedness within the family Pasteurellaceae as determined by genetic transformation. International Journal of Systematic Bacteriology 36, 103-106.

BiRnBoIM, H. C., \& Doly, J. (1979). A rapid alkaline extraction procedure for screening recombinant plasmid DNA. Nucleic Acids Research 7, 1513-1523.

Brosius, J., Dull, T. J., Sleeter, D. D. \& Noller, H. F. (1981). Gene organization and primary structure of a ribosomal RNA operon from Escherichia coli. Journal of Molecular Biology 148, 107-127.

Carbon, P., Ebel, J.-P. \& EhresmanN, C. (1981). The sequence of the ribosomal 16S RNA from Proteus vulgaris: sequence comparison with $E$. coli $16 \mathrm{~S}$ RNA and its use in secondary structure model building. Nucleic Acids Research 9, 2325-2333.

Carlone, G. M., Schalla, W. O., Moss, C. W., Ashley, D. L., Fast, D. M., Holler, J. S. \& Plikaytis, B. D. (1988). Haemophilus ducreyi isoprenoid quinone content and structure determination. International Journal of Systematic Bacteriology 38, 249-253.

Casin, I., Grimont, F., Grimont, P. A. D. \& Sanson-Le Pors, M.-J. (1985). Lack of deoxyribonucleic acid relatedness between Haemophilus ducreyi and other Haemophilus species. International Journal of Systematic Bacteriology 35, 23-25.

Chuba, P. J., Bock, R., Graf, G., Adam, T. \& Göbel, U. (1988). Comparison of 16S rRNA sequences from the family Pasteurellaceae : phylogenetic relatedness by cluster analysis. Journal of General Microbiology 134, 1923-1930.

Dams, E., Hendriks, L., Van de Peer, Y., Neefs, J.-M., Smits, G., VANDENBEMPT, I. \& DE WACHTER, R. (1988). Compilation of small ribosomal subunit RNA sequences. Nucleic Acids Research 16, r87r173.

De Ley, J., Mannheim, W., Mutters, R., Piechulla, K., Tytgat, R., Segers, P., Bisgaard, M., Frederiksen, W., Hinz, K.-H. \& VANHOUCKE, M. (1990). Inter- and intrafamilial similarities of rRNA cistrons of the Pasteurellaceae. International Journal of Systematic Bacteriology 40, 128-139.

Denys, G. A., Chapel, T. A. \& Jeffries, C. D. (1978). An indirect fluorescent antibody technique for Haemophilus ducreyi. Health Laboratory Science 15, 128-132.

Dorsch, M., Moreno, E. \& Stackebrandt, E. (1989). Nucleotide sequence of the 16S rRNA from Brucella abortus. Nucleic Acids Research 17, 1765. 
Edwards, U., Rogall, T., Blöcker, H., Emde, M. \& Bottger, E. C. (1989). Isolation and direct complete nucleotide determination of entire genes. Characterization of a gene coding for $16 \mathrm{~S}$ ribosomal RNA. Nucleic Acids Research 17, 7843-7853.

GuTELl, R. R. \& Fox, G. E. (1988). A compilation of large subunit RNA sequences presented in a structural format. Nucleic Acids Research 16, r175-r269.

HAUN, G. \& GöBEL, U. (1987). Oligonucleotide probes for genus-, species- and subspecies-specific identification of representatives of the genus Proteus. FEMS Microbiology Letters 43, 187-193.

HöPfl, P., Ludwig, W., Schleifer, K. H. \& LaRSEN, N. (1989). The 23S ribosomal RNA higher-order structure of Pseudomonas cepacia and other prokaryotes. European Journal of Biochemistry 185, 355-364.

Huss, V. A. R. \& Sogin, M. L. (1989). Primary structure of the Chlorella vulgaris small subunit ribosomal RNA coding region. Nucleic Acids Research 17, 1255.

Kahn, M., Kolter, R., Thomas, C., Figurski, D., Meyer, R., Remaut, E. \& HelinsKI, D. R. (1979). Plasmid cloning vehicles derived from plasmids ColE1, F, R6K, RK2. Methods in Enzymology 68, 268-280.

KILIAN, M. (1976). A taxonomic study of the genus Haemophilus, with the proposal of a new species. Journal of General Microbiology 93, 9-62.

Kilian, M. \& Biberstein, E. L. (1984). Genus II. Haemophilus Winslow, Broadhurst, Buchanan, Krumwiede, Rogers and Smith 1917, 561 AL. In Bergey's Manual of Systematic Bacteriology, vol. 1, pp. 558-569. Edited by N. R. Krieg \& J. G. Holt. Baltimore: Williams \& Wilkins.

Lane, D. J., Pace, B., Olsen, G. J., Stahl, D. A., Sogin, M. L. \& PACE, N. R. (1985). Rapid determination of 16S rR NA sequences for phylogenetic analyses. Proceedings of the National Academy of Sciences of the United States of America 82, 6955-6959.

Maniatis, T., Fritsch, E. F. \& Sambrook, J. (1982). Molecular Cloning: a Laboratory Manual. Cold Spring Harbor, NY: Cold Spring Harbor Laboratory.

MARMUR, J. A. (1961). A procedure for the isolation of deoxyribonucleic acid from micro-organisms. Journal of Molecular Biology 3, 208-218.

Medlin, L., Elwood, H. J., Stickel, S. \& Sogin, M. L. (1988). The characterization of enzymatically amplified eukaryotic 16S-like rRNA-coding regions. Gene 71, 491-499.

MorSE, S. A. (1989). Chancroid and Haemophilus ducreyi. Clinical Microbiology Reviews 2, 137-157.
Museyi, K., Van Dyck, E., Vervoort, T., Taylor, D., Hoge, C. \& PIOT, P. (1988). Use of an enzyme immunoassay to detect serum IgG antibodies to Haemophilus ducreyi. Journal of Infectious Diseases 157, 1039-1043.

Parsons, L. M., Shayegani, M., Waring, A. L. \& Bopp, L. H. (1989). DNA probes for the identification of Haemophilus ducreyi. Journal of Clinical Microbiology 27, 1441-1445.

Ronald, A. R. \& Albritton, W. L. (1984). Chancroid and Haemophilus ducreyi. In Sexually Transmitted Diseases, pp. 385-393. Edited by K. K. Holmes, P. A. Mardh, P. F. Sparling \& P. J. Wiesner. New York: McGraw-Hill.

Rossau, R., Heyndrickx, L. \& Van Heuverswyn, H. (1988). Nucleotide sequence of a $16 \mathrm{~S}$ ribosomal RNA gene from Neisseria gonorrhoeae. Nucleic Acids Research 16, 6227.

Rossau, R., Vanmechelen, E., De Ley, J. \& Van Heuverswyn, H. (1989). Specific Neisseria gonorrhoeae DNA-probes derived from ribosomal RNA. Journal of General Microbiology 135, 1735-1745.

SANGer, F., Nicklen, S. \& Coulson, A. R. (1977). DNA sequencing with chain terminating inhibitors. Proceedings of the National Academy of Sciences of the United States of America 74, 5463-5467.

Schalla, W. O., SANDers, L. L., Schmid, G. P., TAM, M. R. \& Morse, S. A. (1986). Use of dot-immunobinding and immunofluorescence assays to investigate clinically suspected cases of chancroid. Journal of Infectious Diseases 153, 879-887.

Stackebrandt, E., Murray, R. G. E. \& Trüper, H. G. (1988). Proteobacteria classis nov., a name for the phylogenetic taxon that includes the 'purple bacteria and their relatives'. International Journal of Systematic Bacteriology 38, 321-325.

Tenover, F. C. (1988). Diagnostic deoxyribonucleic acid probes for infectious diseases. Clinical Microbiology Reviews 1, 82-101.

TOSChKa, H. Y., HöPfl, P., LUDWIG, W., SCHLEIFER, K. H., UlbRich, N. \& ERDMANN, V. A. (1987). Complete nucleotide sequence of a $23 \mathrm{~S}$ ribosomal RNA gene from Pseudomonas aeruginosa. Nucleic Acids Research 15, 7182.

TOSCHKA, H. Y., Höpfl, P., LudWig, W., SCHLEIFER, K. H., Ulbrich, N. \& ERdMANN, V. A. (1988). Complete nucleotide sequence of a $16 \mathrm{~S}$ ribosomal RNA gene from Pseudomonas aeruginosa. Nucleic Acids Research 16, 2348.

Viscidi, R. P. \& Yolken, R. G. (1987). Molecular diagnosis of infectious diseases by nucleic acid hybridization. Molecular and Cellular Probes 1, 3-14.

WOESE, C. R. (1987). Bacterial evolution. Microbiological Reviews 51, 221-271. 